\title{
Rola badań marketingowych w pozyskiwaniu wiedzy na potrzeby marketingowego zarządzania przedsiębiorstwem
}

\section{Rola informacji w biznesie}

Jedną z podstawowych umiejętności menedżera jest sprawne funkcjonowanie w realiach rynkowych. $\mathrm{W}$ tym celu konieczne jest dostrzeganie i przewidywanie zarówno długofalowych tendencji i trendów rozwojowych, jak i bieżących zmian zachodzących na rynku. Niezbędna jest także umiejętność podejmowania decyzji o charakterze strategicznym, taktycznym oraz operacyjnym. Aby podołać wskazanym zadaniom nieodzowne jest systematyczne zbieranie, selekcjonowanie i weryfikowanie informacji o rynku i jego uczestnikach.

Informacje pełnią w organizacji wiele funkcji, wśród których jako elementarne można wskazać ${ }^{1}$ :

- funkcję poznawczą,

- funkcję motywacyjną,

- funkcję koordynacyjną,

- funkcję sterująco-kontrolną.

Szczególną funkcję pełnią informacje w procesach decyzyjnych zachodzących w przedsiębiorstwie. Informacje odznaczające się cechami takimi, jak aktualność, dokładność, trafność oraz wiarygodność służą optymalizacji procesu podejmowania decyzji, a tym samym poprawie osiąganych rezultatów i wyników handlowych. Brak właściwych informacji implikuje ryzyko podjęcia decyzji niewłaściwej, niejednokrotnie zgubnej w skutkach. Bez względu na charakter branży, w której działa przedsiębiorstwo, warunkiem skutecznego podejmowania decyzji jest posiadanie dokładnych informacji i właściwe ich wykorzystanie ${ }^{2}$.

${ }^{1}$ K. Bolesta-Kukułka, Decyzje menedżerskie, PWE, Warszawa 2003, s. 75.

2 P. Hague, Badania marketingowe. Planowanie, metodologia i ocena wyników, Helion, Gliwice 2006, s. 14. 
Można przyjąć, że informacje są niezbędne na każdym z etapów procesów decyzyjnych zachodzących w przedsiębiorstwie, poczynając od ujawnienia problemu, poprzez określenie jego charakteru i opracowanie alternatywnych rozwiązań, ich ocenę z perspektywy przewidywanych skutków rozważanych działań, aż do momentu wdrożenia podjętych decyzji oraz oceny ich rezultatów. Zróżnicowanie problemów, na potrzeby których pozyskiwane są informacje, powoduje, iż różny może być także sposób ich wykorzystania. Wśród problemów marketingowych możemy wskazaćs:

- problemy odnoszące się do planowania,

- problemy związane z podejmowaniem decyzji marketingowych,

- problemy odnoszące się do kontrolnych funkcji decyzyjnych.

Oprócz wymiaru decyzyjnego należy uwzględnić także poznawczy wymiar informacji, a więc wzbogacenie wiedzy marketingowej ${ }^{4}$.

Adekwatnie do wskazanych problemów marketingowych, można mówić o instrumentalnym lub koncepcyjnym sposobie użytkowania informacji przez menadżerów ${ }^{5}$. W przypadku problemów stricte decyzyjnych informacje użytkowane są w sposób instrumentalny, co najczęściej sprowadza się bezpośredniego ich wykorzystania w celu rozwiązania zaistniałego problemu marketingowego. Informacje mogą w tym wypadku służyć zarówno do podejmowania krótkoterminowych, jak i długookresowych decyzji w odniesieniu do elementów marketingu mix, jak np. decyzja co do tego, który z projektów produktu należy wdrożyć, jaką cenę ustalić, gdzie i przez kogo powinny być sprzedawane produkty czy jaką kombinację środków przekazu zastosować w ramach działań promocyjnych.

Podobnie instrumentalne podejście zachodzi w przypadku kontroli, gdy informacje służą np. do oceny stopnia zadowolenia klientów, określenia wizerunku organizacji na rynku docelowym lub całkowitego udziału w rynku czy oceny wpływu dokonanych w przeszłości dostosowań w zestawie środków marketingowych. Podejście instrumentalne odnosi się także do wykorzystania informacji w kontekście planowania, np. określenia realnych możliwości rynkowych, tendencji występujących na obsługiwanych rynkach produktowych, przewidywania zmian infrastruktury rynku czy planowania produktu.

Informacja może być także gromadzona w celu uzyskania lepszego obrazu uwarunkowań prowadzenia działalności gospodarczej. Przykładem pozyskiwa-

${ }^{3}$ G. Churchill, Badania marketingowe. Podstawy metodologiczne, Wyd. Nauk. PWN, Warszawa 2002, s. 24.

${ }^{4}$ K. Kędzior, K. Karcz, Badania marketingowe w praktyce, PWE, Warszawa 2007, s. 20.

${ }^{5}$ M. Bartosik-Purgat, H. Mruk, J. Schroeder, Dostepność i wykorzystanie informacji o rynkach i partnerach zagranicznych $w$ procesie internacjonalizacji polskich przedsiębiorstw, Wyd. Uniwersytetu Ekonomicznego w Poznaniu, Poznań 2012, s. 14-15, 32-45. 
nia informacji w kontekście poszerzenia wiedzy rynkowej, uzyskania ogólnego poglądu bądź wzbogacenia wiedzy kierowniczej może być ocena charakteru konkurencji na rynku, określenie pragnień i potrzeb konsumentów czy ocena makroekonomicznych czynników warunkujących prowadzenie działalności gospodarczej, takich jak uwarunkowania prawne i polityczne, tendencje gospodarcze czy społeczne. W kontekście wzbogacenia wiedzy marketingowej możemy mówić o koncepcyjnym wykorzystaniu informacji.

Niezależnie od rodzaju problemów marketingowych pojawiających się w przedsiębiorstwie oraz sposobów wykorzystywania informacji, faktem jest konieczność stałego gromadzenia i przetwarzania danych gospodarczych w celu wsparcia procesów decyzyjnych zachodzących w przedsiębiorstwie. A jednym ze sposobów pozyskiwania precyzyjnych informacji, stosownych do określonego zadania, jest prowadzenie badań marketingowych.

\section{Wiedza jako jeden $\mathrm{z}$ efektów badań marketingowych}

Użytkownikami badań marketingowych są zazwyczaj przedsiębiorstwa, które w obliczu zachodzących procesów rozwoju rynku i wzrostu konkurencji mają coraz większe oczekiwania i potrzeby informacyjne. Cele, których osiągnięciu służyć mają badania marketingowe, wynikają z samej definicji pojęcia tychże badań. Mogą one obejmować rozwiązywanie problemów marketingowych ${ }^{6}$, wsparcie podejmowania decyzji $\mathrm{z}$ zakresu marketingu $\mathrm{w}$ przedsiębiorstwie poprzez ograniczenie zakresu subiektywnych przesłanek oraz oparcie zarządzania marketingiem na bezstronnych i dokładnych podstawach (to znaczy rezultatach badan, przeprowadzonych według określonych zasad metodologicznych) ${ }^{7}$. Celem badań marketingowych może być także zapewnienie pomocy kierownictwu w zrozumieniu otoczenia, zidentyfikowaniu potencjalnych problemów i sprzyjających sytuacji, a tym samym zapewnienie rozwoju i pomoc w skutecznym przeprowadzaniu działań na określonych rynkach ${ }^{8}$. Znaczna część definicji wyraźnie kładzie nacisk na decyzyjny aspekt, ujmując badania marketingowe jako „systematyczny proces gromadzenia informacji, ich przetwarzania, analizy i prezentacji na potrzeby

${ }^{6}$ P. Green, D. Tull, D. Albaum, Research for Marketing Decisions, Prentice Hall, New York 1985, s. 2.

${ }^{7}$ W. Grzegorczyk, Strategie marketingowe przedsiębiorstw na rynkach zagranicznych, Biblioteka Menedżera i Bankowca, Warszawa 2002, s. 11.

${ }^{8}$ S. Kaczmarczyk, Badania marketingowe. Metody i techniki, Wyd. Nauk. PWN, Warszawa 2002, s. 15. 
podejmowania decyzji w firmie" ${ }^{9}$. W kontekście wskazanych funkcji badania marketingowe mają dwa cele: zmniejszenie niepewności w procesie podejmowania decyzji oraz w trakcie planowania działań marketingowych, a następnie kontrolę zrealizowanych przedsięwzięć.

Sposób użytkowania informacji pozyskanych w wyniku badań można przyjąć jako kryterium podziału typów badań marketingowych, dokonując rozróżnienia na badania realizowane dla rozwiązania problemów marketingowych odnoszących się do planowania, badania prowadzone w celu wsparcia bieżących decyzji marketingowych oraz badania odnoszące się do kontrolnych funkcji decyzyjnych. Niezależnie od podziałów czy przyjętych typologii, badania marketingowe, generując informacje o otoczeniu firmy, dostarczają przesłanek dla marketingowego zarządzania przedsiębiorstwem, a w szerszym kontekście wzbogacają wiedzę menedżerów.

Organizowanie procesów pozyskiwania wiedzy, sposobów jej rozpowszechniania i efektywnego wykorzystania stanowi dziś kluczowy element zarządzania. Wiedza urasta współcześnie do rangi jednego z głównych zasobów organizacji, warunkującego jej funkcjonowanie i rozwój. Rola jaką odgrywa wiedza w aspekcie zarządzania przedsiębiorstwem jest ogromna choćby dlatego, iż jej zasoby ${ }^{10}$ :

- stanowią źródło kreowania wartości i osiągania przewagi konkurencyjnej;

- dostarczają menedżerom odpowiedzi na pytania o cel i kierunek działań przedsiębiorstwa;

- umożliwiają zarządzanie teraźniejszością i kształtowanie przyszłości organizacji;

- warunkują sprawność kanałów komunikacji, a tym samym podejmowanie trafnych decyzji i wzrost efektywności organizacji;

- stanowią podstawę kreowania procesów innowacyjnych w organizacji;

- umożliwiają konfigurowanie kluczowych procesów biznesowych;

- wspierają rozwijanie kluczowych kompetencji konkurencyjności.

Wiedza jako efekt badań stanowi jedną z najcenniejszych korzyści osiąganych przez przedsiębiorstwo w wyniku realizacji badań marketingowych. Efektem pierwotnym badań marketingowych są dane surowe, które zostają przekształcone $\mathrm{w}$ informacje, w procesach ich przetwarzania i analizy ${ }^{11}$. Dane i informacje zawarte $\mathrm{w}$ raporcie stanowią efekt bezpośredni badań, natomiast następnym jest wiedza, generowana przez informacje. Wiedza ma zatem pozycję nadrzędną w stosunku do danych i informacji stanowiących dla niej bazę ${ }^{12}$. Wiedza może być definiowa-

${ }^{9}$ E. Hajduk, D. Karaś, D. Szostek, Badania marketingowe w praktyce firm i badaczy, „Marketing i Rynek", 2008, nr 9, s. 21-24.

${ }_{10}$ B. Kaczmarek, W. Walczak, Zarządzanie wiedza we wspótczesnych przedsiębiorstwach, Wyd. Uniwersytetu Łódzkiego, Łódź 2009, s. 13-17.

${ }^{11}$ E. Duliniec, Badania marketingowe w zarządzaniu przedsiębiorstwem, Wyd. Nauk. PWN Warszawa 2002, s. 13-15.

12 W. Grudzewski, I. Hejduk, Zarzadzanie wiedza w przedsiębiorstwach, Difin, Warszawa 2004, s. 73. 
na jako zasób użytecznych informacji zawierających także ogólniejsze wartości oraz doświadczenia i reguły, które umożliwiają ich interpretacje ${ }^{13}$. Wiedza oznacza także zrozumienie ważności i użyteczności aktualnie zdobytych informacji, przekładając się na ich zastosowanie w praktyce. Czynnikami tworzenia wiedzy są ludzie, a zatem budowanie wiedzy warunkują pozyskiwane informacje oraz umiejętności, predyspozycje analityczne i zdolność uczenia się ludzi ${ }^{14}$.

Należy podkreślić, że wiedza powinna służyć udzieleniu odpowiedzi na konkretne pytania, rozwiązaniu konkretnych problemów, osiągnięciu określonego celu czy realizacji zadania. Wiedza zatem przejawia się w praktycznym wykorzystaniu pozyskanych i istotnych dla danego problemu informacji. Wyniki i wnioski z badań wzbogacając wiedzę marketingową menedżerów przyczyniają się do podjęcia trafnych decyzji marketingowych. Decyzje te z kolei powinny przynosić określone rezultaty. Zatem w efekcie umiejętnego wykorzystania informacji i wiedzy pozyskanych w toku badań marketingowych do podejmowania decyzji, przedsiębiorstwo może osiągnąc wymierne rezultaty działań rynkowych, stanowiące ostateczną korzyść, będącą gratyfikacją za trud i koszta związane z realizacją procesów badawczych.

\section{Pozyskiwanie wiedzy w toku badań marketingowych w praktyce przedsiębiorstw}

Jak już wspomniano, informacje uzyskane z badań marketingowych mają nie tylko wartość decyzyjną, ale i poznawczą, poszerzającą wiedzę o zjawiskach i procesach zachodzących na rynku. Badania marketingowe poprzez realizację swojej podstawowej funkcji umożliwiają pozyskanie zasobu wiedzy niezbędnego dla podejmowania decyzji oraz lepszego zrozumienie otoczenia prowadzonego biznesu i zachodzących w nim zmian.

Na tle przedstawionych rozważań postanowiono przyjrzeć się, w jaki sposób przedsiębiorstwa zaspokajają zapotrzebowanie informacyjne w kontekście wsparcia procesów zarządczych oraz budują wiedzę niezbędną w tym zakresie, a także jaką rolę odgrywają na tym polu badania marketingowe. Wnioskowanie przeprowadzono na podstawie wyników badania empirycznego przeprowadzonego jesienią 2011 roku przez Katedrę Marketingu Uniwersytetu Łódzkiego. Badanie stanowiło część projektu badawczego dotyczącego użyteczności badań marketingowych w praktyce przedsiębiorstw, prowadzonego w latach 2011-2013 ${ }^{15}$.

${ }^{13}$ A. Koźmiński, Zarządzanie w warunkach niepewności, Wyd. Nauk. PWN, Warszawa 2005, s. 94.

${ }^{14}$ B. Kaczmarek, W. Walczak, op. cit., s. 51-54.

${ }^{15}$ Cząstkowe wyniki zaprezentowano także m.in. w pracach: B. Gregor, M. Kalińska-Kula, Użyteczność badań marketingowych $w$ procesach decyzyjnych przedsiębiorstwa, „Handel 
Zakres przestrzenny badania obejmował podmioty gospodarcze z obszaru województwa łódzkiego. Badaniem objęto 235 przedsiębiorstw, które w okresie ostatnich dwóch lat prowadziły badania marketingowe. Jednostki badania dobrano do próby przy wykorzystaniu metody doboru nieprobabilistycznego - poprzez dobór celowy, korzystając z bazy adresowej udostępnionej przez Wojewódzki Urząd Statystyczny. Badanie realizowano za pomocą techniki wywiadu indywidualnego, prowadzonego z przedstawicielami kierownictwa firmy albo z osobami odpowiedzialnymi za badania lub, w szerszym zakresie, działania marketingowe w firmie (właściciel, prezes, dyrektor, kierownik działu marketingu bądź kierownik działu sprzedaży). Narzędziem badawczym był kwestionariusz wywiadu.

Dobierając próbę starano się uwzględnić podmioty małe i duże, o różnym profilu działalności (produkcyjne, handlowe, usługowe), reprezentujące poszczególne ogniwa rynku (produkcja, hurt, detal), działające w sektorze B2C i B2B. Strukturę próby z punktu widzenia cech przedsiębiorstw zaprezentowano w tab. 1 .

Tabela 1. Rozkład próby w zależności od cech przedsiębiorstw oraz stopnia realizacji badań marketingowych

\begin{tabular}{|l|l|c|c|}
\hline \multicolumn{2}{|c|}{ Cechy przedsiębiorstwa } & $\begin{array}{c}\text { Liczba badanych } \\
\text { przedsiębiorstw }\end{array}$ & $\begin{array}{c}\text { Odsetek przedsiębiorstw, } \\
\text { które w ostatnich 2 latach } \\
\text { przeprowadzily badania } \\
\text { marketingowe }\end{array}$ \\
\hline \multirow{3}{*}{$\begin{array}{l}\text { Liczba zatrud- } \\
\text { nionych pra- } \\
\text { cowników }\end{array}$} & poniżej 10 & 117 & 73,5 \\
\cline { 2 - 4 } & od 10 do 49 & 73 & 72,6 \\
\cline { 2 - 4 } & od 50 do 249 & 36 & 75,0 \\
\cline { 2 - 4 } & powyżej 250 & 9 & 100,0 \\
\hline \multirow{3}{*}{$\begin{array}{l}\text { Charakter } \\
\text { prowadzonej } \\
\text { działalnósi }\end{array}$} & produkcja & 50 & 72,0 \\
\cline { 2 - 4 } & handel hurtowy & 18 & 88,9 \\
\cline { 2 - 4 } & handel detaliczny & 50 & 72,0 \\
\cline { 2 - 4 } & usługi & 117 & 74,4 \\
\hline \multirow{2}{*}{$\begin{array}{l}\text { Sektor } \\
\text { działania }\end{array}$} & B2B & 76 & 75,0 \\
\cline { 2 - 4 } & B2C & 159 & 74,2 \\
\hline Ogółem & & 235 & 74,5 \\
\hline
\end{tabular}

Źródło: opracowanie własne.

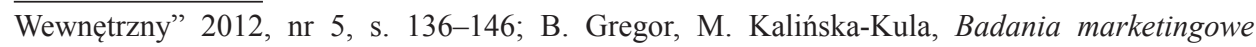
w praktyce przedsiębiorstw regionu łódzkiego, Wyd. Nauk. Uniwersytetu Szczecińskiego, Szczecin 2012, s. 423-434. 
Okazało się, że $75 \%$ przedsiębiorstw, które znalazły się w próbie, prowadziło badania marketingowe w ciągu ostatnich dwóch lat. Dominowały w tej grupie przedsiębiorstwa, duże oraz firmy działające w hurtowym ogniwie handlu. Natomiast jedna czwarta badanych nie prowadziła badań marketingowych w zakresie czasowym, którego dotyczyło badanie. Respondenci najczęściej uzasadniali to brakiem odczuwania potrzeby pozyskiwania informacji w drodze takich badań (powód taki wskazało $40 \%$ badanych). Część respondentów stwierdziła, że specyfika rynku (mała konkurencja, niewielka dynamika rynku, oligopolistyczna struktura) powoduje brak konieczności prowadzenia badań. Blisko 30\% respondentów podało jako argument brak środków finansowych, a 25\% stwierdziło, iż decyzje podejmowane są w przedsiębiorstwie rutynowo i oparte na doświadczeniu menedżerów.

Jednak zdecydowana większość, bo $175 \mathrm{z}$ badanych przedstawicieli przedsiębiorstw, przyznała, że prowadzono badania marketingowe. Łącznie zidentyfikowano 183 przypadki zrealizowanych pomiarów. W większości badania te dostarczyły informacji niezbędnych do podjęcia określonych, opisanych przez respondentów decyzji. Wiedza pozyskana w drodze przeprowadzonych badań pozwoliła także przedsiębiorstwom na lepsze rozeznanie w zakresie szeroko rozumianego otoczenia prowadzonego biznesu.

W toku przeprowadzonych studiów przeanalizowano podawane przez respondentów problemy marketingowe, dla których rozwiązania pozyskiwana była niezbędna wiedza i które stanowiły przyczyny prowadzonych badań. Rozkład procentowy odpowiedzi na temat rodzaju problemów marketingowych zaprezentowano na rys. 1 . Niestety odnotowano przypadki, gdy problem marketingowy nie został sprecyzowany przez respondenta, był niejasny lub niejednoznaczny. Sytuacje takie stanowiły przeszło jedną czwartą analizowanych przypadków i zostały ujęte w ramach kategorii „brak problemu”.

W świetle otrzymanych wyników, badania marketingowe najczęściej (47\% badanych przypadków) prowadzone były w celu zapewnienia wsparcia informacyjnego procesów decyzyjnych, zachodzących w kontekście krótkoterminowych i długookresowych decyzji, dotyczących dostosowania elementów marketingu mix. Problemy te stanowiły blisko 30\% wskazań i najczęściej dotyczyły kwestii takich, jak wprowadzenie na rynek nowego produktu, poszerzenie asortymentu przedsiębiorstwa, dostosowanie oferty produktowej do oczekiwań nabywców, zmiana zakresu usług firmy. Często wskazywaną przyczyną prowadzenia badań była także konieczność ustalenia ceny produktów lub dostosowania jej poziomu do cen konkurentów (bądź w szerszym kontekście optymalizacja strategii cenowej). Kolejną przesłankę stanowiły kwestie dostosowania działań z zakresu 
komunikacji marketingowej, w tym przygotowanie strategii promocji, wybór narzędzi i środków przekazu, zwiększenie skuteczności lub efektywności działań reklamowych, a także zmiana opakowania produktu oraz dostosowanie kanałów dystrybucji. Powodem prowadzania badań marketingowych często było także dopracowanie funkcjonalności i skuteczności strony internetowej. Respondenci wskazywali także na problemy marketingowe, na przykład zwiększenie zasięgu przestrzennego sprzedaży, optymalizację zasilenia materiałowego (wybór dostawców), określenie przyczyn spadku lub stagnacji sprzedaży.

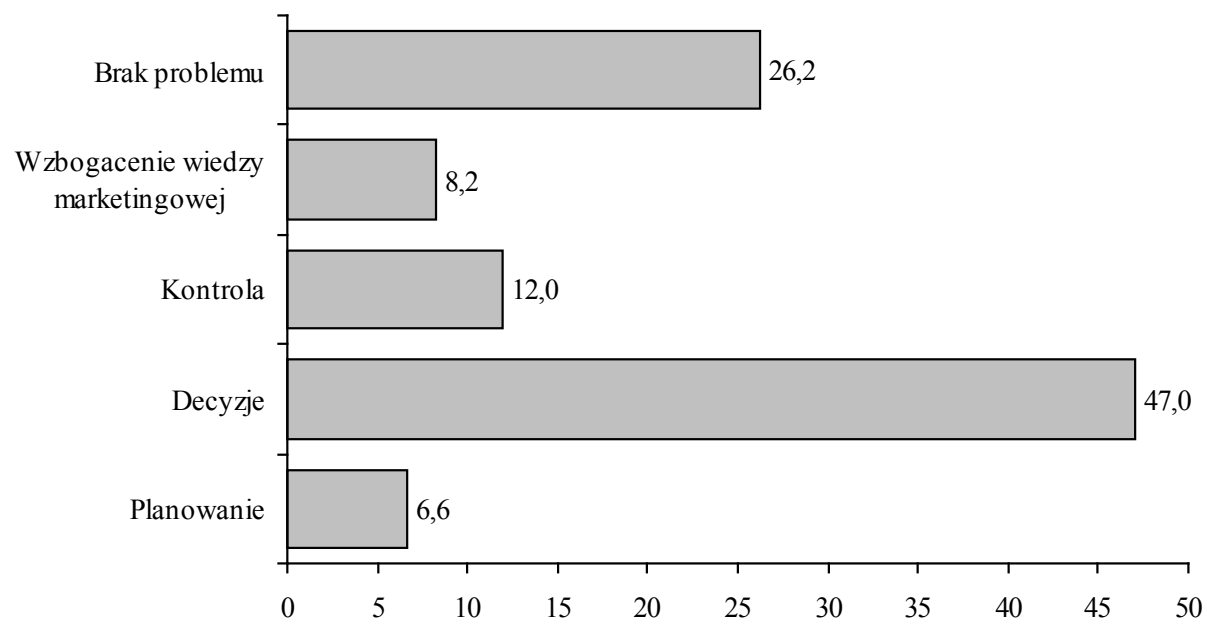

Rysunek 1. Przyczyny pozyskiwania informacji w drodze badań marketingowych (w \%)

Źródło: opracowanie własne.

Zdecydowanie mniej liczną grupę stanowiły problemy dotyczące kontroli (12\% przypadków), które miały na celu wyodrębnienie czynności i marketingowych funkcji sprawiających trudności oraz ocenę działań zakończonych bądź będących w trakcie realizacji. Tutaj respondenci zwracali uwagę na dostosowanie poziomu obsługi klienta, określenie zadowolenia i satysfakcji klienta, ocenę obsługi oraz jakości świadczonych usług, a także ocenę satysfakcji i zadowolenia pracowników. Wskazywano także na problemy związane z oceną skuteczności działań reklamowych, określeniem stopnia rozpoznawalności marki oraz oceną wizerunku marki.

Najmniej liczną grupę $(6,6 \%)$ stanowiły problemy marketingowe z zakresu planowania, w których przypadku istotne były kwestie skupiające się wokół analizy możliwości rynkowych, takie jak zidentyfikowanie niszy rynkowej, wejście na nowy rynek, ocena realnych możliwości rynkowych, określenie tendencji rozwojowej rynku (wzrostowa czy spadkowa) oraz charakterystyka klienta. 
Respondenci wskazali jako przyczynę prowadzenia badań marketingowych potrzebę uzyskania lepszego obrazu otoczenia prowadzonej działalności gospodarczej, przy czym problemy w tym obszarze koncentrowały się głównie na charakteryzowaniu otoczenia konkurencyjnego oraz rozpoznaniu potrzeb i oczekiwań nabywców. W obszarze wzbogacenia wiedzy marketingowej wskazywano przyczyny prowadzenia pomiarów, tj. uzyskanie obrazu warunków otoczenia konkurencyjnego, określenie pozycji konkurencyjnej, pomiar opinii i preferencji klienta, przygotowanie profilu klienta i charakterystyka jego oczekiwań.

Analizując strukturę problemów marketingowych, dla których pozyskiwano wiedzę w toku prowadzonych badań, w kontekście charakterystyki badanych przedsiębiorstw można zauważyć pewne prawidłowości (szczegółowy rozkład odpowiedzi zaprezentowano w tab. 2).

Tabela 2. Struktura problemów marketingowych w zależności od cech przedsiębiorstwa

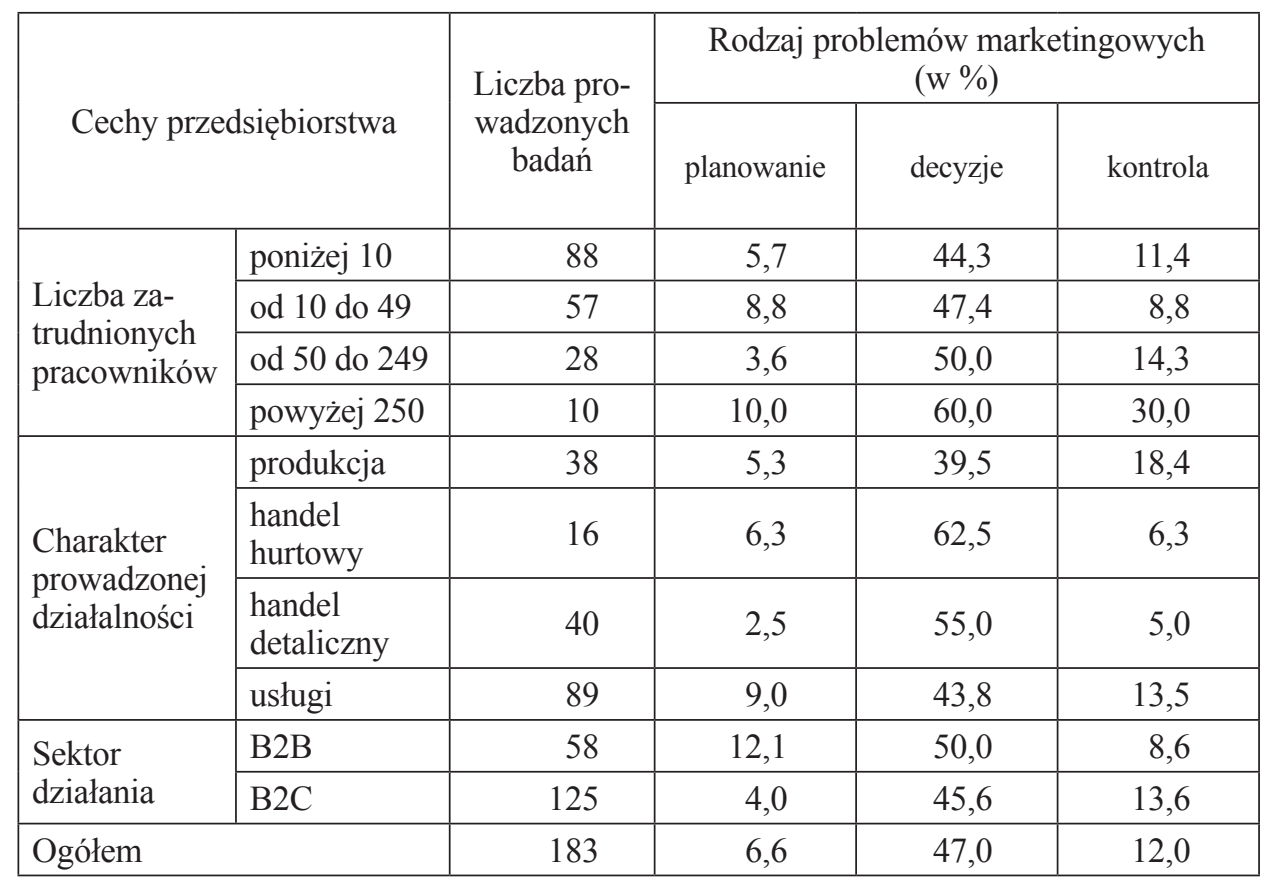

Źródło: opracowanie własne.

Wiedzę na potrzeby wsparcia podejmowanych decyzji gromadziła przeszło połowa przedsiębiorstw dużych i średnich. Odsetek ten był nieco niższy w przypadku firm małych i mikro, ale różnice nie były wyraźne. Co ciekawe, zdecydowanie częściej informacje $\mathrm{w}$ tym obszarze były gromadzone przez przedsiębior- 
stwa prowadzące działalność handlową, w szczególności hurtowników (blisko $60 \%$ badanych) niż przez firmy produkcyjne.

W kontekście planowania wiedzę pozyskiwano wyraźnie częściej w firmach reprezentujących sektor bussines to bussines - było to $12 \%$ badanych firm, podczas gdy w przypadku firm z sektora B2C odsetek ten wynosił jedynie 4\%. Stosunkowo częściej informacje w tym zakresie były wykorzystywane także przez firmy usługowe oraz firmy duże. Zaskakuje fakt, że porównywalnie często wiedzę taką gromadziły firmy małe oraz przedsiębiorstwa duże.

Na potrzeby realizacji funkcji kontrolnych w przedsiębiorstwie wiedza gromadzona była zdecydowanie częściej przez firmy duże (blisko 30\% badanych). Pewne różnice, choć już mniej znaczące, można dostrzec także w przypadku przedsiębiorstw produkcyjnych, które gromadziły informacje w tym obszarze częściej niż firmy handlowe czy usługowe. Podobnie częściej wiedzę dla celów kontroli pozyskiwały podmioty obsługujące indywidualnych nabywców niż przedsiębiorstwa z sektora B2B.

Patrząc na przedstawiony rozkład wyników można zauważyć, iż na zapotrzebowanie informacyjne oraz gromadzone zasoby wiedzy w pewnym stopniu wpływają cechy charakteryzujące przedsiębiorstwo, takie jak jego wielkość, charakter prowadzonej działalności czy sektor obsługiwanego rynku. Nie jest to zaskakujące spostrzeżenie, wiedza pozyskiwana przez organizację musi być bowiem adekwatna do warunków prowadzonej przez nią działalności oraz rynkowego otoczenia biznesu.

\section{Zakończenie}

Wiedza powstająca na bazie informacji rynkowej i marketingowej jest obecnie postrzegana jako strategiczny zasób organizacji, a umiejętne jej wykorzystanie stanowi kluczowy czynnik pozyskania przewagi konkurencyjnej, w dalszej zaś perspektywie przetrwania przedsiębiorstwa. Pozyskiwanie wiedzy staje się nieodzownym procesem oraz wyzwaniem dla współczesnych przedsiębiorstw, a badania marketingowe, poprzez realizację swoich podstawowych funkcji, mogą stanowić istotną pomoc w tym zakresie. Badania te umożliwiają pozyskanie zasobu wiedzy niezbędnego dla podejmowania decyzji, przygotowania planów, realizacji funkcji kontrolnych oraz lepszego zrozumienie otoczenia prowadzonego biznesu i zachodzących w nim zmian. Informacje uzyskane z badań marketingowych mają zatem nie tylko wartość decyzyjną, ale i poznawczą, poszerzającą wiedzę o zjawiskach i procesach zachodzących na rynku. Badane przedsiębiorstw starają się 
budować niezbędną wiedzę w kontekście wsparcia procesów zarządczych, między innymi na podstawie informacji pozyskiwanych w toku prowadzonych badań marketingowych.

\section{Bibliografia}

Bartosik-Purgat M., Mruk H., Schroeder J., Dostępność i wykorzystanie informacji o rynkach $i$ partnerach zagranicznych $w$ procesie internacjonalizacji polskich przedsiębiorstw, Wyd. Uniwersytetu Ekonomicznego w Poznaniu, Poznań 2012

Bolesta-Kukułka K., Decyzje menedżerskie, PWE, Warszawa 2003

Churchill G., Badania marketingowe. Podstawy metodologiczne, Wyd. Nauk. PWN, Warszawa 2002

Duliniec E., Badania marketingowe w zarządzaniu przedsiębiorstwem, Wyd. Nauk. PWN, Warszawa 2002

Green P., Tull D., Albaum D., Research for Marketing Decisions, Prentice Hall, New York 1985

Gregor B., Kalińska-Kula M., Badania marketingowe w praktyce przedsiębiorstw regionu tódzkiego, Wyd. Nauk. Uniwersytetu Szczecińskiego, Szczecin 2012

Gregor B., Kalińska-Kula M., Użyteczność badań marketingowych w procesach decyzyjnych przedsiębiorstwa, „Handel Wewnętrzny” 2012, nr 5

Grudzewski W., Hejduk I., Zarzadzanie wiedza w przedsiębiorstwach, Difin, Warszawa 2004

Grzegorczyk W., Strategie marketingowe przedsiębiorstw na rynkach zagranicznych, Biblioteka Menedżera i Bankowca, Warszawa 2002

Hague P., Badania marketingowe. Planowanie, metodologia i ocena wyników, Helion, Gliwice 2006

Hajduk E., Karaś D., Szostek D., Badania marketingowe w praktyce firm i badaczy, „Marketing i Rynek” 2008, nr 9

Kaczmarczyk S., Badania marketingowe. Metody i techniki, Wyd. Nauk. PWN, Warszawa 2002

Kaczmarek B., Walczak W., Zarządzanie wiedza we wspótczesnych przedsiębiorstwach, Wyd. Uniwersytetu Łódzkiego, Łódź 2009

Kędzior K., Karcz K., Badania marketingowe w praktyce, PWE, Warszawa 2007 Koźmiński A., Zarządzanie w warunkach niepewności, Wyd. Nauk. PWN, Warszawa 2005 